\title{
Abnormalities of In Vitro Immunoglobulin Synthesis by Peripheral Blood Lymphocytes from Untreated Patients with Hodgkin's Disease
}

\author{
S. Romagnani, G. F. Del Prete, E. Maggi, G. Bellesi, G. Biti, \\ P. L. Rossi FERrini, and M. RICCI, Departments of Clinical \\ Immunology, Hematology, and Radiotherapy, University of Florence, \\ Policlinico di Careggi, 50134-Florence, Italy
}

\begin{abstract}
A B S TRACT The immunoglobulin-synthesizing activities of peripheral blood mononuclear cells from 57 untreated patients with Hodgkin's disease and 47 normal subjects were compared. Cumulative amounts of IgM and IgG synthesized and secreted by unstimulated and pokeweed mitogen-stimulated cells over a 7-d period were determined in a solid-phase radioimmunoassay. Synthesis of IgM in unstimulated cultures and of both IgM and IgG in cultures stimulated with pokeweed mitogen was markedly reduced in patients with Hodgkin's disease, whereas the mean level of the spontaneous IgG synthesis was enhanced. The degree and frequency of in vitro abnormalities were not influenced by disease stage or histology.

Depression of pokeweed mitogen-induced immunoglobulin synthesis did not correlate with excessive number of monocytes and it was unaffected by removal of phagocytic cells or addition to the cultures of monocytes from normal individuals. On the other hand, monocytes isolated from blood of patients with Hodgkin's disease were even more effective than normal monocytes in supporting pokeweed mitogen-induced immunoglobulin synthesis by normal phagocyte-depleted mononuclear cells. Synthesis of both IgM and IgG induced by pokeweed mitogen remained subnormal after addition to patient $B$ cell cultures of autologous irradiated $T$ cells or allogeneic normal $T$ lymphocytes. T cells from patients with Hodgkin's disease appeared at least as effective as normal $\mathrm{T}$ cells in helping pokeweed mitogen-induced immunoglobulin production by normal B cells. However, when normal $T$ cells were co-cultured with $B$ cells from patients with Hodgkin's disease, spontaneous IgG synthesis declined, whereas the addition of patient $T$ cells
\end{abstract}

Received for publication 21 May 1982 and in revised form 26 November 1982. to normal B cells resulted in an increase of spontaneous IgG synthesis. In patients showing depression of pokeweed mitogen-induced immunoglobulin synthesis the lymphoproliferative response and immunoglobulin synthesis stimulated by Staphylococcus aureus bacteria of the Cowan first strain, a $\mathrm{T}$ cell independent $B$ cell mitogen, were also markedly reduced.

These studies demonstrate impairment of immunoglobulin synthesis by cultured lymphocytes from untreated patients with Hodgkin's disease after stimulation with polyclonal B cell activators and suggest that the in vitro abnormalities may be, at least in part, the result of a preexisting in vivo activation of lymphocytes in Hodgkin's disease patients.

\section{INTRODUCTION}

Patients with Hodgkin's disease (HD)' frequently have impaired cell-mediated immunity, as demonstrated by anergy to recall skin tests (1), failure of dinitrochlorobenzene sensitization (2), and impairment of in vitro lymphocyte proliferation induced by mitogens (3-5), recall antigens $(6,7)$, or allogeneic cells $(8)$.

In contrast to cell-mediated immunity, antibody responses to immunization with various antigens are usually normal (1) and serum immunoglobulin (Ig) levels are normal or elevated $(9,10)$ in untreated patients with HD.

This study was undertaken to evaluate the capacity of peripheral blood lymphocytes from untreated patients with HD to produce Ig in vitro after stimulation

\footnotetext{
${ }^{1}$ Abbreviations used in this paper: Cowan Staph, Staphylococcus aureus bacteria Cowan first strain; E-RFC, E-rosette-forming cells; FCS, fetal calf serum; HD, Hodgkin's disease; MNC, mononuclear cells; PWM, pokeweed mitogen; $\mathrm{sIg}^{+}$cells, surface immunoglobulin-bearing cells; SRBC, sheep erythrocytes.
} 
with pokeweed mitogen (PWM) and Staphylococcus aureus bacteria of the Cowan first strain (Cowan Staph) polyclonal B cell activators. Either PWM- or Cowan Staph-induced IgM and IgG production were found to be significantly reduced and there was enhanced spontaneous in vitro IgG synthesis by B cells in a number of untreated patients with $\mathrm{HD}$.

\section{METHODS}

Subjects. Studies were performed on 57 freshly diagnosed, untreated patients with histologically proven HD seen at the Hematology Department and Institute of Radiology of the University Medical School of Florence from 1979 to 1982 . The median age was $37 \mathrm{yr}$ with an age range of $9-73 \mathrm{yr} .31$ patients were male and 26 female. 11 patients had clinical stage I, 28 stage II, 12 stage III, and 6 stage IV disease (11). 48 patients had class $A$ and 9 class B symptoms. The histology was mixed cellularity in 30 , nodular sclerosis in 24 , lymphocyte predominance in 2 , and lymphocyte depletion in 1 patient. As controls, 47 normal individuals, consisting of laboratory personnel, roughly similar in age and sex distribution to the patients with HD, were tested. In addition, 24 patients with inflammatory chronic disorders (12 with chronic lymphocytic thyroiditis, 6 with rheumatoid arthritis, and 6 with chronic bronchitis) were included in the study. None of these patients had received steroids or immunosuppressive drugs for at least 3 mo before testing.

Mononuclear cell (MNC) separation and identification. MNC were prepared by density sedimentation of heparinized blood over Ficoll-Hypaque and washed in RPMI 1640 medium plus $5 \%$ fetal calf serum (FCS; Gibco Laboratories, Grand Island Biological Co., Grand Island, NY). Phagocytic cells were removed from MNC suspensions by incubation for $45 \mathrm{~min}$ with carbonyl iron (GAF, Mancester) (5). More than $80 \%$ of monocytes were removed by this technique as determined by nonspecific esterase staining (12).

To obtain fractions enriched in B lymphocytes, phagocytedepleted MNC suspensions were deprived of $\mathrm{T}$ cells by a double E-rosetting procedure with neuraminidase-treated sheep erythrocytes (SRBC) (13). These non-T, nonphagocytic, MNC suspensions contained $<1 \%$ E-rosette-forming cells (E-RFC) and $<5 \%$ nonspecific esterase-staining cells. The percentage of surface immunoglobulin-bearing cells $\left(\operatorname{sIg}^{+}\right)$was evaluated in non-T, nonphagocytic, cell suspensions from $22 \mathrm{HD}$ patients and in those of 24 normal subjects by rosetting with a mixture of erythrocytes coated with anti$\mu$ - or anti- $\delta$-chain immunosorbent-purified rabbit antibodies (14). The mean value $( \pm \mathrm{SE})$ in HD patients $(46.2 \pm 1.3 \%)$ did not significantly differ from that of normal controls $(47.1 \pm 1.4 \%)$.

Purified T cells were prepared by a double-E-rosetting procedure with neuraminidase-treated SRBC (13). These purified $\mathrm{T}$ cell suspensions contained $>95 \%$ E-RFC and $<1 \%$ $\mathrm{sIg}^{+}$cells.

Monocyte-rich fractions were obtained by discontinuous density gradient centrifugation on Percoll (Pharmacia Fine Chemicals, Uppsala) according to the technique described by Kurnick et al. (15). The fractions recovered at the interface between 40 and $50 \%$ Percoll solutions contained $>85 \%$ nonspecific esterase-staining cells and $<10 \%$ lymphocytes. In some experiments monocyte-rich fractions were also prepared using adherence technique to FCS-coated plastic surfaces, as reported by Kurland and Bockman (16).

In 15 normal subjects and 21 patients with HD percentages of monocytic cells were evaluated either on Wright-Giemsastained smears of whole blood or in MNC suspensions using two monoclonal antibodies. The OKMl antibody, reactive with antigens expressed on the membrane of human monocytes and granulocytes (17), was purchased from Ortho Pharmaceutical Corp. (Raritan, NJ). The M-12 antibody, reactive with adherent phagocytic monocytes and polymorphonuclear cells (18) was a gift of Dr. M. Cooper and Dr. S. Hanjan (University of Alabama, Birmingham). Both monoclonal reagents were used in indirect immunofluorescence with a rabbit $F\left(a^{\prime}\right)_{2}$ anti-mouse polyvalent immunoglobulin conjugated with fluorescein isothiocyanate.

Ig culture system. Duplicate cultures were prepared in round-bottomed polystyrene tubes. Unless otherwise stated, each culture contained $1 \times 10^{6}$ cells, $0.9 \mathrm{ml}$ of RPMI medium with antibiotics and $2 \mathrm{mM} 1$-glutamine added, and $0.1 \mathrm{ml}$ heat-inactivated FCS. Co-cultures consisting of combinations of monocyte-rich fractions and phagocyte-depleted populations or $T$ cell- and $B$ cell-enriched fractions from normal subjects and HD patients were also carried out. In these co-culture systems concentrations of monocytes ranging between $2 \times 10^{4}$ and $0.5 \times 10^{6}$ were added to $1 \times 10^{6}$ phagocyte-depleted MNC. In co-cultures of $\mathrm{T}$ and $\mathrm{B}$ cells, $1 \times 10^{6} \mathrm{~T}$ lymphocytes were added to $0.2 \times 10^{6} \mathrm{~B}$ cellenriched fractions, since this $\mathrm{T}$ to $\mathrm{B}$ cell ratio roughly mirrors that of unfractionated MNC suspensions and it had been found optimal in a series of preliminary experiments. Cultures were stimulated with PWM (Gibco Laboratories) (5 $\mu \mathrm{l} / \mathrm{ml})$ or Cowan Staph $\left(4 \times 10^{6}\right.$ bacteria $\left./ \mathrm{ml}\right)$, which had been prepared as detailed elsewhere (13). All cultures were maintained in an incubator under a $5 \% \mathrm{CO}_{2}$ atmosphere at $37^{\circ} \mathrm{C}$ for $7 \mathrm{~d}$.

Measurement of IgM and IgG levels in culture supernatants. The amount of $\operatorname{IgM}$ and IgG protein secreted by cells into the supernatants was determined by a solid-phase radioimmunoassay. The assay was performed in microtiter plates filled with purified polyclonal $\operatorname{IgM}$ or $\lg$ at a concentration of $10 \mu \mathrm{g} / \mathrm{ml}$. After overnight incubation, the coating solution was removed, the wells washed and incubated again with $10 \%$ bovine serum albumin to saturate any remaining protein-binding surface. The wells were then incubated overnight at $4^{\circ} \mathrm{C}$ with samples to be assayed and monospecific ${ }^{125}$ I-labeled anti- $\mu$ - or anti- $\gamma$-chain antibodies, prepared in rabbit and purified as detailed elsewhere (14). After washings, the individual wells were cut apart and the bound radioactivity was determined. For each radioimmunoassay a 10 point standard curve of $\operatorname{IgM}$ and $\operatorname{IgG}$ was performed in parallel with the culture samples on each plate. The sensitivity of this assay ranged between 100 and 20,000 $\mathrm{ng} \mathrm{Ig} / \mathrm{ml}$

Lymphoproliferative culture system. Assay for DNA synthesis was performed as detailed in previous papers $(13,14)$.

\section{RESULTS}

Spontaneous and PWM-induced Ig synthesis in patients with HD. We measured IgM and IgG synthesis by MNC from 47 control subjects and 57 untreated patients with HD in unstimulated cultures and in cultures stimulated with PWM. As shown in Table I, IgM synthesis from patient MNC was significantly reduced either in the absence $(P<0.002)$ or in the presence of PWM $(P<0.0005)$. IgG production by $\mathrm{MNC}$ from patients with HD was reduced in the pres- 
TABLE I

Spontaneous and PWM-induced IgG and IgM Synthesis In Vitro by MNC

from Untreated Patients with HD

\begin{tabular}{|c|c|c|c|c|c|}
\hline \multirow[b]{2}{*}{ Subject group } & \multirow[b]{2}{*}{$\begin{array}{l}\text { No. of } \\
\text { cases }\end{array}$} & \multicolumn{2}{|c|}{ IgG synthesis } & \multicolumn{2}{|c|}{ IgM synthesis } \\
\hline & & - & PWM & - & PWM \\
\hline & & \multicolumn{2}{|c|}{$n g / 10^{\circ}$ cells } & \multicolumn{2}{|c|}{$\mathrm{ng} / 10^{\circ}$ cells } \\
\hline HD & 57 & $1,340 \pm 105$ & $3,122 \pm 592$ & $325 \pm 63$ & $1,409 \pm 265$ \\
\hline Normal controls & 47 & $909 \pm 105$ & $4,592 \pm 587$ & $658 \pm 115$ & $3,950 \pm 525$ \\
\hline \multicolumn{6}{|l|}{ Chronic inflammatory } \\
\hline disorders $^{\circ}$ & 24 & $726 \pm 78$ & $5,398 \pm 876$ & $540 \pm 91$ & $3,194 \pm 418$ \\
\hline
\end{tabular}

ence of PWM $(P<0.01)$, whereas in the absence of PWM significantly raised IgG synthesis was observed by MNC of HD $(P<0.002)$. In the disease control group, consisting of 24 patients with chronic inflammatory disorders, but not $\mathrm{HD}$, the mean values of spontaneous and PWM-induced IgM synthesis were not significantly different from those of normal controls.

We could not find any relationship between depressed PWM-induced Ig synthesis in HD patients and clinical stage or histologic type of the disease. Likewise, there was no correlation between increase of the spontaneous IgG synthesis and stage or histology.

Evaluation of monocytic cell function in PWMstimulated cultures. Monocytic cells have been shown to be essential for PWM-induced differentiation of B cells, but when present in excessive numbers, they are capable of suppressing Ig production induced by PWM. Therefore, in a group of 21 patients with HD we searched for a quantitative relationship between monocyte percentages and depression of Ig synthesis. Although monocyte percentages determined on Wright-Giemsa-stained smears of whole blood of patients $(4.9 \pm 0.6)$ were not significantly different from those of normal controls (5.2 \pm 0.5$)$, Ficoll-Hypaquepurified MNC suspensions from HD patients usually showed higher proportions of monocytes than control subjects, as detected by OKM1 (27.9 \pm 2.5 vs. $19.9 \pm 1$; $P<0.002)$ and $\mathrm{M}-12(23.4 \pm 2.2$ vs. $14.8 \pm 1.3 ; P<0.005)$ monoclonal antibodies. However, depression of PWMinduced Ig synthesis was found in patients with either increased or normal percentages of monocytes. Depression of PWM-induced Ig synthesis could not be related to increased suppressor activity of monocytic cells. In fact, as shown in Table II, synthesis of both IgG and IgM was not enhanced after removal of the majority of phagocytic cells by incubation with carbonyl iron.

In another series of 12 separate experiments phago- cyte-depleted MNC and irradiated monocyte-rich fractions, prepared by discontinuous gradient centrifugation, from blood of normal subjects or HD patients were co-cultured reciprocally in the presence of PWM. The addition of different concentrations of normal monocytes did not result in any significant increase of PWM-induced Ig synthesis by phagocyte-depleted MNC from HD patients. On the other hand, monocyterich fraction from HD patients were as effective as normal monocytes in supporting PWM-induced Ig synthesis by phagocyte-depleted MNC from normal individuals (data not shown). Comparable results were obtained when monocytes enriched by a different separation procedure, such as adherence to plastic surfaces, were used.

Study of helper and suppressor $T$ cell activity in unstimulated and PWM-stimulated co-cultures. To exclude the possibility that an exaggerated $T$ suppressor activity was responsible for depression of PWM-induced Ig synthesis in patients with HD, the ability of different concentrations of $T$ cells from HD patients to support PWM-induced Ig synthesis by autologous B cell-rich fractions was evaluated. Furthermore, parallel cultures were established with irradiated $(2,000 \mathrm{rad}) \mathrm{T}$ cells, because this treatment has been shown to remove the majority of suppressor $T$ lymphocyte activity (19). As shown in Table III, PWMinduced production of both IgM and IgG in the presence of irradiated $T$ cells was increased either in normal controls or HD patients, but it remained subnormal in co-cultures of all HD patients tested.

In another series of 18 experiments $T$ and $B$ cellrich fractions from normal or HD MNC were co-cultured reciprocally in the absence or in the presence of PWM and Ig levels in the culture supernatants were measured. The addition of normal $T$ cells to $B$ cellrich fractions from HD patients did not result in any significant increase of PWM-induced IgM or IgG pro- 
TABLE II

Effect of Phagocytic Cell Removal on the PWM-induced Ig Synthesis by MNC from Untreated Patients with HD and Normal Donors

\begin{tabular}{|c|c|c|c|c|c|}
\hline \multirow[b]{2}{*}{ Donors } & \multirow{2}{*}{$\begin{array}{l}\text { No. of } \\
\text { caseses }\end{array}$} & \multirow[b]{2}{*}{ MNC used in culture } & \multirow[b]{2}{*}{ Stimulant } & \multicolumn{2}{|c|}{ Ig synthesis } \\
\hline & & & & $\lg M$ & $\operatorname{IgG}$ \\
\hline & & & & $n g /$ & ${ }^{6} \mathrm{cells}$ \\
\hline \multirow[t]{4}{*}{ HD } & 24 & Unfractionated $^{\bullet}$ & None & $265 \pm 61 \ddagger$ & $1,042 \pm 154$ \\
\hline & & & PWM & $1,097 \pm 228$ & $1,615 \pm 299$ \\
\hline & & Phagocyte-depleted $\S$ & None & $500 \pm 94$ & $1,101 \pm 168$ \\
\hline & & & PWM & $1,042 \pm 208$ & $1,737 \pm 362$ \\
\hline \multirow[t]{4}{*}{ Normal subjects } & 18 & Unfractionated & None & $578 \pm 98$ & $711 \pm 115$ \\
\hline & & & PWM & $4,116 \pm 495$ & $4,368 \pm 612$ \\
\hline & & Phagocyte-depleted & None & $993 \pm 201$ & $819 \pm 134$ \\
\hline & & & PWM & $3,804 \pm 691$ & $4,590 \pm 716$ \\
\hline
\end{tabular}

- Ficoll-Hypaque-purified MNC.

$\downarrow$ Mean value \pm SE.

\$ Phagocytic cells were removed from MNC by incubation with carbonyl iron.

duction. On the other hand, purified T cells from HD patients, whose MNC showed subnormal PWM-induced Ig synthesis in vitro, were at least as effective as normal $\mathrm{T}$ cells in helping normal $\mathrm{B}$ cell-rich fractions to produce either IgM or IgG molecules in the presence of PWM (data not shown). The outcome of co-cultures between patient or normal $B$ cells and allogeneic $\mathrm{T}$ cells in the absence of PWM disclosed a complex system of cellular interactions (Table IV). T

TABLE III

PWM-induced Ig Synthesis by B Cell-rich Fractions from Normal Subjects and Untreated Patients with HD Cultured with Autologous Unirradiated and Irradiated T Lymphocytes

\begin{tabular}{lll}
\hline & \multicolumn{2}{c}{ Ig synthesis } \\
\cline { 2 - 3 } Type of co-culture & \multicolumn{1}{c}{$\operatorname{lgM}$} & \multicolumn{1}{c}{$\operatorname{lgG}$} \\
\hline & \multicolumn{2}{c}{ ng/culture } \\
Normal B cells & $3,060 \pm 346 \pm$ & $4,619 \pm 302$ \\
T cells & $8,662 \pm 1,102$ & $8,451 \pm 1,054$ \\
T cells (irradiated) & & \\
Patient B cells & $1,245 \pm 147$ & $2,097 \pm 378$ \\
T cells & $2,170 \pm 399$ & $3,370 \pm 809$ \\
T cells (irradiated) &
\end{tabular}

- $1 \times 10^{6}$ unirradiated or irradiated $(2,000 \mathrm{rad}) \mathrm{T}$ cells were cultured with $0.2 \times 10^{6}$ autologous $\mathrm{B}$ cells in the presence of the optimal concentration of PWM (5 $\mu \mathrm{l} /$ culture).

$\ddagger$ Mean value $\pm \mathrm{SE}$ of six separate experiments. cells from normal donors significantly inhibited the synthetic rate of patient $B$ cells in comparison with either autologous T cells $(P<0.002)$ or allogeneic $\mathrm{T}$ cells from patients with HD $(P<0.05)$. In contrast, $T$ cells from patients with HD enhanced the endogenous activity of normal B cells in comparison with either autologous T cells $(P<0.02)$ or allogeneic normal $\mathrm{T}$ cells $(P<0.05)$, but they failed to influence the spontaneous production of IgM by normal B cells.

Reduced proliferative response and Ig synthesis

TABLE IV

Effect of Co-culturing Reciprocally $T$ and B Cells from Normal Subjects and Patients with HD on the Spontaneous IgG Production In Vitro

\begin{tabular}{lc}
\hline \multicolumn{1}{c}{ Type of co-culture } & Spontaneous IgG production \\
\hline & $n g /$ culture \\
Normal B cells & $909 \pm 180 \ddagger$ \\
Autologous T cells & $1,023 \pm 142$ \\
Allogeneic normal T cells & $1,423 \pm 168$ \\
Allogeneic HD T cells & \\
HD B cells & $1,456 \pm 288$ \\
Autologous T cells & $1,088 \pm 143$ \\
Allogeneic HD T cells & $788 \pm 98$ \\
Allogeneic normal T cells &
\end{tabular}

- $0.2 \times 10^{6} \mathrm{~B}$ cell-rich fractions were co-cultured with $1.0 \times 10^{6}$ purified $\mathrm{T}$ cells in $1 \mathrm{ml}$ of medium.

$\$$ Mean value \pm SE of 27 separate experiments. 
to Cowan Staph by blood cells from patients with HD. The functional capacity of B lymphocytes from 36 patients showing depression of PWM-induced Ig synthesis was also evaluated by the use of Cowan Staph. Cowan Staph-induced IgM synthesis in untreated patients with HD $\left(2,459 \pm 604 \mathrm{ng} \mathrm{Ig} / 10^{6}\right.$ cells $)$ was significantly lower than that of normal controls $\left(5,265 \pm 696 \mathrm{ng} \mathrm{Ig} / 10^{6}\right.$ cells; $\left.P<0.002\right)$. Likewise, Cowan Staph-induced IgG production in the same patients $\left(2,076 \pm 427 \mathrm{ng} \mathrm{Ig} / 10^{6}\right.$ cells) was markedly depressed in comparison with that of control group $\left(3,485 \pm 392 \mathrm{ng}\right.$ Ig/ $10^{6}$ cells; $\left.\boldsymbol{P}<0.005\right)$.

The lymphoproliferative response to Cowan Staph was examined in cultures of either unfractionated MNC or their B cell-enriched fractions using different concentrations of bacteria and a 3-d incubation period. As illustrated in Fig. 1, either MNC cultures or cultures of B cell-enriched fractions from these patients exhibited significant impairment of the proliferative response.

\section{DISCUSSION}

This paper summarizes the results of our studies assessing B cell functional ability in vitro in a group of untreated patients with HD. We found that the majority of patients had depressed IgM and IgG production induced by PWM. This confirms a previous report showing subnormal PWM-induced production of IgM, IgG, and IgA in a smaller group of untreated patients with HD (20).

Several explanations for the reduced Ig production can be offered. Since Ig synthesis induced by PWM is subject to the regulatory activity of monocytes (21, 22 ), the abnormality could be associated with an increase in the number of these cells relative to lymphocytes in MNC suspensions (23). Indeed, using monoclonal antibodies reactive with monocytic cells we could confirm a recent report showing higher concentrations of monocytes in Ficoll-Hypaque MNC suspensions from patients with HD than in controls (20). However, since PWM-induced Ig synthesis was subnormal in patients with either raised or normal percentages of monocytes, factors other than suppression mediated by excessive number of monocytoid cells are probably involved in the impairment of PWM-driven Ig synthesis. Attention has recently been focused upon excessive suppressor activity of monocytes as responsible for mitogen hyporesponsiveness (24) or reduced $T$ colony formation (25) in patients with HD. In this study, we could not demonstrate that depression of PWM-induced Ig synthesis in vitro was due to an exaggerated suppressor activity of monocytic cells.

Since PWM-induced Ig production is under control of $\mathrm{T}$ lymphocytes, an alternative explanation for depressed Ig synthesis could be that HD patients have

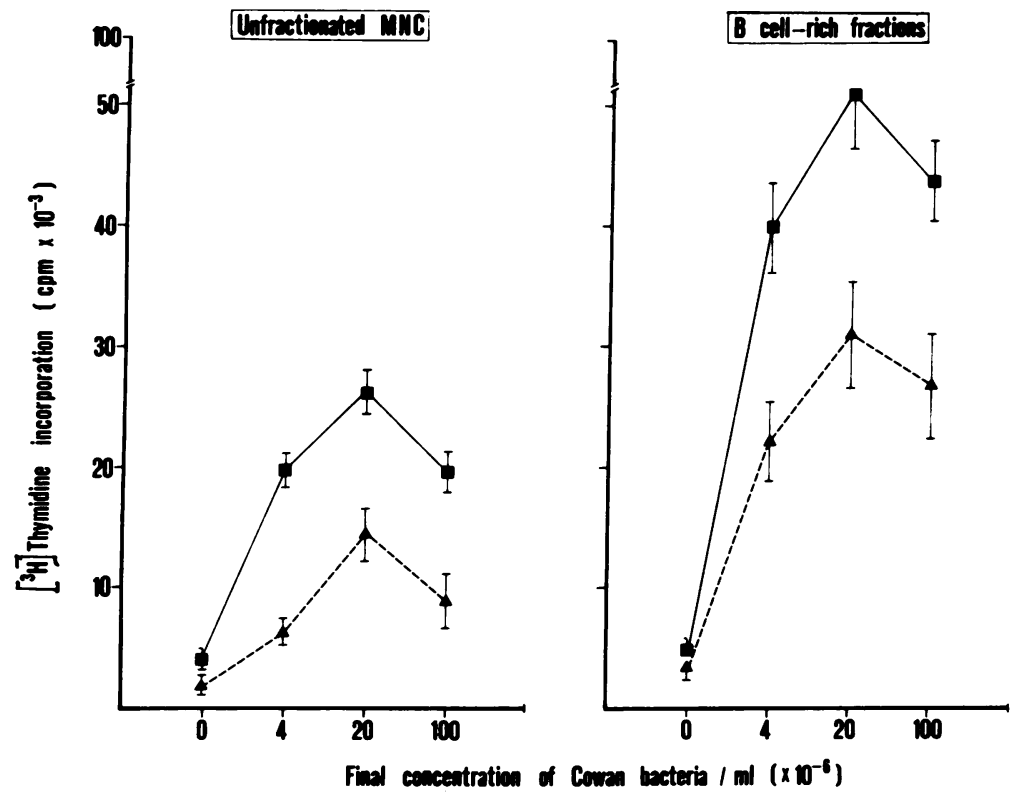

FIGURE 1 Cowan Staph proliferative response (mean cpm \pm SE) of MNC and B cell-rich fractions from 47 normal subjects $(\square)$ and 36 untreated patients with HD (ム). The difference between the peak response of control group and HD is statistically significant $(P<0.0005)$. 
exaggerated suppressor $\mathrm{T}$ cell function or impaired helper $T$ cell function. The results reported in this paper argue against both of these possibilities. First, PWM-induced Ig synthesis by B cells from HD patients still remained subnormal after removal of suppressor $\mathrm{T}$ cell activity by irradiation of T lymphocytes. Second, the use of normal $\mathrm{T}$ cells in the place of patient $\mathrm{T}$ cells did not restore the ability of $B$ cell-rich fractions from HD patients to produce normal amounts of Ig after stimulation with PWM. Finally, T lymphocytes from patients appeared at least as effective as normal $\mathrm{T}$ cells in helping PWM-induced Ig production by normal B cells. Taken together, these findings suggest that, unlike $\mathrm{T}$ cell functions related to the effector apparatus, helper and suppressor activities of $\mathrm{T}$ lymphocytes are probably spared in patients with HD.

Thus, the question arises as to whether depression of PWM-induced Ig synthesis in patients with HD is due, at least in part, to abnormalities of B lymphocytes. The results reported herein showed that the proliferative response and Ig production in vitro in the presence of Cowan Staph by MNC from HD patients showing depression of PWM-induced Ig synthesis were also consistently reduced. Taking into account that Cowan Staph is one of the few activators that may stimulate proliferation of blood B cells in the absence of $\mathrm{T}$ lymphocytes (13), it is tempting to speculate that depression of Ig synthesis induced in vitro by polyclonal B cell activators in patients with $\mathrm{HD}$ mainly reflects an altered function of $\mathrm{B}$ lymphocytes. This possibility was also supported by the observation that a number of patients with HD have enhanced spontaneous IgG production in vitro. In this respect, our data are in agreement with previous demonstrations of enhanced IgG synthesis by cultured splenic lymphocytes (26), as well as with findings indicating substantial increase of serum IgG, IgA, IgD, IgE levels (27-29), and antibodies against Epstein-Barr and other viral antigens (30, 31) in patients with HD. Depressed Ig synthesis after stimulation with PWM, associated with enhanced spontaneous IgG synthesis, has also been reported in patients with systemic lupus erythematosus $(32,33)$ and Henoch-Schönlein purpura (34) and attributed to an excessive $B$ cell stimulation in vivo (35-38).

Excessive B cell stimulation may result from endogenous or exogenous polyclonal B cell activation, as well as altered $\mathbf{T}$ cell regulation. The results presented herein showed that when B cells from HD patients were co-cultured with normal T cells spontaneous IgG synthesis declined. Since we could exclude the possibility that normal $T$ cells were affected by products of HD B cells, such as anti-T antibodies, it is reasonable to suppose that the reduction of spontaneous IgG production in vitro reflects differences in the regulatory ability of normal and HD T lymphocytes. This possibility was further supported by the observation that the addition of $T$ cells from $H D$ patients to normal $B$ cells resulted in an increase of the spontaneous IgG synthesis. One explanation could be that in HD patients suppressor $\mathrm{T}$ cells, obviously distinct from those involved in the regulation of PWM-induced Ig synthesis, are impaired. An alternative explanation is that not only B cells, but also helper $\mathrm{T}$ cells were already activated in vivo. This concept is in agreement with previous reports showing the presence in $\mathrm{HD}$ of circulating lymphoid cells, prevalently $T$ in nature (39), which spontaneously synthesize DNA $(40,41)$ and show similarities with lymphocytes detectable under conditions of known antigenic challenge $(42,43)$. It is also consistent with the demonstration of in vivo production of migration-inhibitory lymphokinelike substances (44). The origin of the activation of $B$ and/ or helper $\mathrm{T}$ cells in HD is still unknown. It has been suggested that this activation may represent the result of a lymphocyte 'civil war' or of a chronic stimulation by tumor-associated antigens or tumor-inducing virus (45-47). Our data do not deal with the mechanisms potentially responsible for the activated state of lymphocytes in HD. However, they support the interpretation that persistent exposure in vivo of immunoreactive lymphoid cells to unknown HD-related stimulus may play an important role in the derangement of immunity in HD.

\section{ACKNOWLEDGMENTS}

We are grateful to Dr. M. Cooper and to Dr. S. N. S. Hanjian for generous gift of the M-12 monoclonal reagent and to Mr. G. Fiumara for his excellent technical assistance.

This work was supported by the following grants: finalized project "Control of Tumor Growth" of Consiglio Nazionale delle Ricerche 81.1455.96; Consiglio Nazionale delle Ricerche CT 81.00187.04, and Ministero Pubblica Istruzione 01862.

\section{REFERENCES}

1. Aisenberg, A. C. 1966. Immunological status of Hodgkin's disease. Cancer. 19: 385-394.

2. Eltringham, J. R., and H. S. Kaplan. 1973. Impaired delayed hypersensitivity responses in 154 patients with untreated Hodgkin's disease. Natl. Cancer Inst. Monogr. 36: $107-115$.

3. Matchett, K. M., A. T. Huang, and W. B. Kremer. 1973. Impaired lymphocyte transformation in Hodgkin's disease. J. Clin. Invest. 52: 1908-1917.

4. Levy, R. A., and H. S. Kaplan. 1974. Impaired lymphocyte function in untreated Hodgkin's disease. N. Engl. J. Med. 290: 181-184.

5. Romagnani, S., A. Amadori, G. Biti, G. Bellesi, and M. Ricci. 1976. In vitro lymphocyte response to phytomitogens in untreated and treated patients with Hodgkin's disease. Int. Arch. Allergy Appl. Immunol. 51: 378-389. 
6. De Gast, G. C., M. R. Halie, and H. O. Nieweg. 1975. Immunological responsiveness against two primary antigens in untreated patients with Hodgkin's disease. Eur. J. Cancer. 11: 217-224.

7. Romagnani, S., A. Amadori, E. Maggi, R. Biagiotti, and M. Ricci. 1977. Study of some immunological parameters in untreated patients with Hodgkin's disease. Int. Arch. Allergy Appl. Immunol. 55: 429-438.

8. Björkholm, M., G. Holm, H. Mellstedt, and D. Petterson. 1975. Immunological capacity of lymphocytes from untreated patients with Hodgkin's disease evaluated in mixed lymphocyte culture. Clin. Exp. Immunol. 22: 373-377.

9. Wagener, D. J. T., P. J. J. Van Munster, and C. Haanen. 1976. The immunoglobulins in Hodgkin's disease. Eur. J. Cancer. 12: 683-688.

10. Amlot, P. L., and L. Green. 1979. Serum immunoglobulin G, A, M, D, and E concentrations in lymphomas. Br. J. Cancer. 40: 371-379.

11. Carbone, P. P., H. S. Kaplan, K. Mushoff, D. W. Smothers, and M. Tubiana. 1971. Report of the committee of Hodgkin's disease staging classification. Cancer Res. 31: 1860-1861.

12. Koski, I. R., D. G. Poplack, and R. M. Blaese. 1976. A nonspecific esterase stain for the identification of monocytes and macrophages. In In Vitro Methods in Cellmediated and Tumor Immunity. B. R. Bloom and J. R. David, editors. Academic Press, Inc., New York, San Francisco, London. 359-368.

13. Romagnani, S., A. Amadori, M. G. Giudizi, R. Biagiotti, E. Maggi, and M. Ricci. 1978. Different mitogenic activity of soluble and insoluble staphylococcal protein A (SPA). Immunology. 35: 471-478.

14. Romagnani, S., M. G. Giudizi, R. Biagiotti, F. Almerigogna, E. Maggi, G. F. Del Prete, and M. Ricci. 1981 Surface immunoglobulins are involved in the interaction of protein A with human B cells and in the triggering of B cell proliferation induced by protein A-containing Staphylococcus aureus. J. Immunol. 127: 1307-1313.

15. Kurnick, J. T., L. Östbert, M. Stegagno, A. K. Kimura, A. Örh, and O. Sjöberg. 1979. A rapid method for the separation of functional lymphoid cell populations of human and animal origin on PVP-silica (Percoll) density gradient. Scand. J. Immunol. 10: 563-573.

16. Kurland, J. I., and R. S. Bockman. 1978. Prostaglandin $\mathrm{E}$ production by human blood monocytes and mouse peritoneal macrophages. J. Exp. Med. 147: 952-957.

17. Breard, J., E. L. Reinherz, P. C. Kung, G. Goldstein, and S. F. Schlossman. 1980. A monoclonal antibody reactive with human peripheral blood monocytes. J. Immunol. 124: 1943-1948.

18. Hanjan, S. N. S., and M. D. Cooper. 1981. Monoclonal antibodies reactive with human monocytes, polymorphonuclear cells, and activated T cells. Fed. Proc. 40: 1095a. (Abstr.)

19. Siegal, F. P., and M. Siegal. 1977. Enhancement by irradiated $T$ cells of human plasma cells production: dissection of human helper and suppressor function in vitro. J. Immunol. 118: 642-647.

20. Twomey, J. J., A. H. Laughter, L. Rice, and R. Ford. 1980. Spectrum of immunodeficiencies with Hodgkin's disease. J. Clin. Invest. 66: 629-637.

21. Montazeri, G., N. Chiorazzi, S. M. Fu, and H. G. Kunkel. 1980. Regulatory role of circulating monocytes in the differentiative and proliferative responses of human $B$ lymphocytes. Clin. Immunol. Immunopathol. 16: 1-10.
22. Gmelig-Meyling, F., and T. A. Waldmann. 1981. Human $B$ cell activation in vitro: augmentation and suppression by monocytes of the immunoglobulin production induced by various B cell stimulants. J. Immunol. 126: 529-537.

23. Schecter, G. P., and F. Soehnlen. 1978. Monocyte-mediated inhibition of lymphocyte blastogenesis in Hodgkin's disease. Blood. 52: 261-271.

24. Goodwin, J. S., R. P. Messner, A. D. Bankhurst, G. T. Peake, J. H. Saiki, and R. C. Williams, Jr. 1977. Prostaglandin-producing suppressor cells in Hodgkin's disease. N. Engl. J. Med. 297: 963-968.

25. Bockman, R. S. 1980 . Stage-dependent reduction in $T$ colony formation in Hodgkin's disease. Coincidence with monocyte synthesis of prostaglandins. J. Clin. Invest. 66: 523-531.

26. Longmire, R. L., R. Mc Millan, R. Yelenosky, S. Armstrong, J. E. Lang, and C. G. Craddock. 1973. In vitro splenic IgG synthesis in Hodgkin's disease. N. Engl. J. Med. 289: 763-767.

27. Romagnani, S., R. Biagiotti, A. Amadori, E. Maggi, G Biti, G. Bellesi, and M. Ricci. 1980. Hyperproduction of IgE and T-cell dysfunction in Hodgkin's disease. Int. Arch. Allergy Appl. Immunol. 63: 64-72.

28. Amlot, P. L., and L. Green. 1978. Atopy and immunoglobulin $\mathrm{E}$ concentration in Hodgkin's disease and other lymphomas. Br. Med. J. 1: 327-329.

29. Corte, G., M. Ferrarini, P. Tonda, and A. Bargellesi. 1977. Increased serum IgD concentration in patients with Hodgkin's disease. Clin. Exp. Immunol. 28: 359362 .

30. Langenhuysen, M. M. A., T. Cazemier, B. Honwen, T. M. Brouwers, M. R. Halie, T. H. The, and H. D. Nieweg. 1974. Antibodies to Epstein-Barr virus, cytomegalovirus, and Australia antigen in Hodgkin's disease. Cancer. 34: 262-267.

31. Mochanko, K., M. Fejes, D. M. Breazauscek, A. Suarez, and A. E. Bachmann. 1979. The relation between Epstein-Barr virus antibodies and clinical symptomatology and immunodeficiency in patients with Hodgkin's disease. Cancer. 44: 2065-2070.

32. Jasin, H., and M. Ziff. 1975. Immunoglobulin synthesis by peripheral blood cells in systemic lupus erythematosus. Arthritis Rheum. 18: 219-228.

33. Blaese, R. M., J. Grayson, and A. D. Steinberg. 1980 Increased immunoglobulin-secreting cells in the blood of patients with active systemic lupus erythematosus. Am. J. Med. 69: 345-350.

34. Beale, M. G., G. S. Nash, M. J. Bertovich, and R. P. Mac Dermott. 1982. Similar disturbances in B cell activity and regulatory $T$ cell function in Henoch-Schönlein purpura and systemic lupus erythematosus. J. Immunol. 128: 486-491.

35. Bobrove, A. M., and P. Miller. 1977. Depressed in vitro B-lymphocyte differentiation in systemic lupus erythematosus. Arthritis Rheum. 20: 1326-1333.

36. Nies, K. W., and J. S. Louie. 1978. Impaired immunoglobulin synthesis by peripheral blood lymphocytes in systemic lupus erythematosus. Arthritis Rheum. 21: 5157.

37. Ginsburg, W. W., F. D. Finkelman, and P. E. Lipsky. 1979. Circulating and pokeweed mitogen-induced immunoglobulin-secreting cells in systemic lupus erythematosus. Clin. Exp. Immunol. 35: 76-88.

38. Okudaira, K., K. Tanimoto, T. Nakamura, and Y. Horiuchi. 1980. Spontaneous enhanced in vitro immuno- 
globulin synthesis by B cells in systemic lupus erythematosus. Clin. Immunol. Immunopathol. 16: 267-278.

39. Huber, C., G. Michlmayr, M. Falkensamer, U. Fink, G. Zur Nedden, $H$. Braunsteiner, and H. Huber. 1975. Increased proliferation of $\mathbf{T}$ lymphocytes in the blood of patients with Hodgkin's disease. Clin. Exp. Immunol. 21: 47-53.

40. Crowther, D., G. H. Fairley, and R. L. Sewell. 1969. Significance of the changes in the circulating lymphoid cells in Hodgkin's disease. Br. Med. I. 2: 473-477.

41. Holm, G., H. Mellstedt, M. Björkholm, B. Johansson, D. Killander, R. Sundblad, and G. Soderberg. 1976. Lymphocyte abnormalities in untreated patients with Hodgkin's disease. Cancer. 37: 751-762.

42. Ehrnst, A., B. Lambert, and A. Fagraeus. 1978. DNA synthesis in subpopulations of blood mononuclear leu- kocytes in human subjects after vaccination against yellow fever. Scand. J. Immunol. 8: 339-346.

43. Crowther, D., G. Hamilton Fairley, and R. L. Sewell. 1969. Lymphoid cellular responses in the blood after immunization in man. J. Exp. Med. 129: 849-863.

44. Cohen, S., B. Fisher, T. Yoshida, and R. E. Bettigole. 1974. Serum migration-inhibitory activity in patients with lymphoproliferative diseases. N. Engl. J. Med. 290: 882-886.

45. Order, S. E., and S. Hellman. 1972. Pathogenesis of Hodgkin's disease. Lancet. 1: 571-573.

46. De Vita, V. T. 1973. Lymphocyte reactivity in Hodgkin's disease: a lymphocyte civil war. N. Engl. J. Med. 289: 801-802.

47. Long, J. C., A. C. Aisenberg, and P. C. Zamecnik. 1977. Chromatographic and electrophoretic analysis of an antigen in Hodgkin's disease tissue cultures. Proc. Natl. Acad. Sci. USA. 70: 1540-1544. 